\title{
Profit allocation in an integrated European market
}

\author{
Fred C. de Hosson, Caron \& Stevens/Baker \& McKenzie, Amsterdam
}

That the increasing integration of markets in the EC Member States within the framework of the Single Market project has a vital impact is obvious in the manner in which enterprises operate. Perhaps one of the most striking phenomena is the tendency of larger, usually American, enterprises to part with their country-wise structure. The prospect of one single market where goods and services, capital and persons flow freely is definitely causing greater integration of enterprise sections, which before used to be active in separate (protected) national submarkets. An important additional stimulus to the integration process has been the evolution in technology, traffic, communication, standardization and production.

In an integrated enterprise operating in different EC Member States, it is increasingly difficult to use the arm's length principle. The fact that the enterprise draws its strength from the integration of its sections - that is, avoids sections operating separately - is entirely at odds with the philosophy that profits can be allocated realistically only by adhering to the arm's length principle. McLure noted that this development might well lead the Member States to adopt within the EC a unitary method and formula apportionment. ${ }^{1}$ Unlike McLure, I am not optimistic about the EC Member States accepting such profit allocation methods in the foreseeable future. On the contrary, the sometimes vehement dispute between the different EC member countries and the United States over the application by some US states of the worldwide unitary method has only increased European aversion to this method.

Nor does the increasing use of branches in the different Member States offer much prospect of an increase of the use of some sort of unitary method (the Merger Directive, in particular, will undoubtedly result in a substantial increase in the number of branches). Although, in principle, the tax treaties which are based on the OECD Model Treaties allow for an 'indirect method', any effective application is permitted only if the method is common practice in that particular sector of industry, and, additionally, the result must be not very much different from the allocation under the arm's length method. Moreover, the development of case law and doctrine rather reinforces the notional independence of branches and the related integral application of the arm's length method. ${ }^{2}$

The observation that any acceptance in formal rules and regulations of a unitary method must be excluded for the time being does not mean that there are no developments in this field. It is expected that companies will now be looking for structures allowing partial or integral application of a unitary method in an informal manner. One example of this trend is the increased use of 'cost-sharing' arrangements, whereby the costs of centrally rendered services and centralised $R \& D$ are divided among the participating group companies on the basis of a formula. This kind of method of allocating costs via a formula approach has, in practice, been accepted by all Member States, provided that companies meet prerequisites and file documentation that may at times be far-reaching. Quite a more advanced method is the use of partnerships as vehicles for profit-sharing arrangements which are based on a formula approach between the participating group companies/partners. In an international context, however, partnerships may easily cause considerable problems as to characterization and permanent establishment. The introduction of the European Economic Interest Grouping has shown abundantly that the permanent establishment issue in particular cannot be easily resolved.

${ }^{1}$ Charles E. McLure Jr., 'European Integration and Taxation of Corporate Income at Source: Lessons from the U.S.' in Malcolm Gammie and Bill Robinson Beyond 1992: A European Tax System, the Institute for Fiscal Studies, pp. 39-51. See Helmut Becker, The determination of income of a permanent establishment or branch, Intertax 1989/1, pp.
$12-15$. 
I expect the coming years will see the introduction of pooling arrangements, which will be more suitable vehicles for sharing profits within a group of companies on the basis of a formula. Although not quite devoid of problems, pooling arrangements seem to pose fewer difficulties than partnership arrangements. In practice, unwilling tax authorities sometimes try to prevent pooling between group companies, arguing that the conclusion of the agreement in and of itself constitutes an act which does not meet the arm's length criterion. For instance, if the participating group companies conduct operations of a different kind, the authorities take the view that similar unaffiliated parties would never have joined such a pooling agreement, and that the pooling arrangement as such can thus be set aside. I am of the opinion that this argument is incorrect. Even the arm's length principle does not disregard the existence of the group as such. The arm's length principle merely aims to divide the total profit among the group companies involved, with due observance of existing group relations. This presumption can also be found in Article 9 of the OECD Model Treaty, which permits corrections only if the conditions made between related companies in their commercial or financial relations differ from those between unrelated companies. The provision does not relate to the commercial relations themselves.

However, finding fully acceptable 'arm's length' pooling conditions is not helped by the fact that unrelated parties may not make similar pooling agreements. The ultimate question confronting companies in this respect is how to apply the arm's length principle to the formula approach. In practice, the answer can be found only in composing the formula in such a manner that a link is created with the profit allocation in past years according to the arm's length principle. There will be situations, however, where the resulting determination of the profit capacity of the group companies involved will be acceptable only for a limited period of time.

Perhaps it is time to have another look at functional analysis after all.

\title{
Securities in movables in German law: an outline
}

\author{
Rolf Serick, Kurt Lipstein and Stefan A. Riesenfield \\ Translated by Tony Weir
}

Originally published in the German language, this book is now available for those international practising lawyers looking for an outline on the essentlal features of the German law of securities in movables.

International business communities will be able to learn how far, under the present and proposed law, they can count on securities in movables offered by their German trading partners for goods supplied on credit or money lent.

Summary of the toples discussed:

- Comparisons with English and American Law

- Security Transfers

- Retention of title

- Transfer for security purposes

- German practice regarding fiduciary security assignments, bulk

assignments in factoring and the collection of debits

- Security interests in movables "Made in Germany"

- The reform of insolvency law and the law of securities in movables in

Germany.

Softcover, 184 pages

ISBN 9065444815

Price: Dfl. 110,- US\$ 61.-

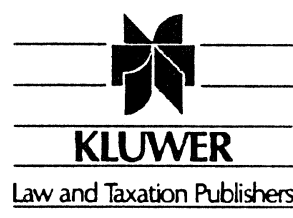

Also available from your bookseller. 